\title{
Synthesis and characterization of $\mathbf{N}, \mathbf{N}^{\prime}$-bis (isatin) diamino zirconium (IV) complexes
}

\author{
A. Sarker ${ }^{1}$, T. Hossain ${ }^{1}$, M. N. Bashir ${ }^{1}$, K. J. Fatema ${ }^{2}$ and A. K. M. L. Rahman ${ }^{1 *}$ \\ ${ }^{I}$ Department of Chemistry, Jagannath University, Dhaka 1100 \\ ${ }^{2}$ Chemistry Division, Atomic Energy Center, BAEC, Dhaka 1000
}

Received: 02 December 2018

Revised: 01 April 2019

Accepted: 06 May 2019

DOI: https://doi.org/10.3329/bjsir.v54i4.44564

\begin{abstract}
$\mathrm{N}, \mathrm{N}^{\prime}$-bis (isatin) diamine schiff base ligands were synthesized by the condensation reaction of Isatin with various diamine (ethane-1,2-diamine, propane-1,3-diamine and hexane-1,6-diamine) in 2:1 molar ratios. These ligands were used to prepare $\mathrm{Zr}$ (IV) complexes. Prepared ligands and complexes were characterized by using conductance measurement, FT-IR, UV-Visible and ${ }^{1} \mathrm{HNMR}$ spectroscopy. The presence of FT-IR band for azomethine group supports the formation of ligand. Vibrational bands for $\mathrm{Zr} \leftarrow \mathrm{N}$ and $\mathrm{Zr} \leftarrow \mathrm{O}$ in complexes signify the coordination through $\mathrm{O}$ and $\mathrm{N}$ sites of ligands. ${ }^{1} \mathrm{HNMR}$ peak for $\mathrm{NH}$ moiety in ligand gets almost disappeared in complex reveals tautomerism of $\mathrm{NH}$ with nearby carbonyl oxygen due to the effect of complexation. The absence of peak above $500 \mathrm{~nm}$ in the electronic spectra indicates $\mathrm{d}^{0}$ system of zirconium in complexes. The elemental analytical data was analogous to theoretical composition of ligands and complexes. The molar conductance values obtained for the complexes represent their non-electrolytic character.
\end{abstract}

Keywords: N, N'-bis (isatin) diamine; Schiff base ligands; zirconium(IV) complexes; tautomerism in complexation; FT-IR and ${ }^{1} \mathrm{HNMR}$ spectroscopy

\section{Introduction}

1H-indole-2,3-dione, commonly known as Isatin, is one of the leading class of oxo-derivative indoles with synthetic versatility. It is used as building entity of a broad range of alkaloids, drugs, pesticides and dyes (Konstantinovic et al., 2015). Isatin and its derivatives possess antimicrobial, antiviral, anticonvulsive, antitumor, anti-HIV, anti-inflammatory and antimycobacterial activity (Mathur and Nain, 2014). It acts as potent antagonist on trial natriuretic peptide receptors in vitro (Sonawane and Tripathi, 2013). Therefore, medicinal and biological values of isatin have attracted the research community in developing ligand with effective capturing ability like Schiff bases. Schiff bases are used as substances in the preparation of a number of industrial and biologically active compounds via ring closure, cycloaddition and replacement reaction. On the industrial scale, they have wide range of applications such as dyes and pigments. Goyat et al. (2016) synthesized N, N'-Bis (indol -2-oxo-3-ylidene)-1, 2-Diaminoethane and N, N'-Bis (indol -2-oxo-3-ylidene)-1, 3-Diaminopropane Schiff base complexes of tellurium(IV) and found $92 \%$ and $91 \%$ inhibiting activity against Mycobacterium tuberculosis compared to Rifampin standard. Konstantinovic et al. (2015) synthesized of isatin-3-(4'-hydroxy) benzoylhydrazone and observed their inhibiting activity against the Gram-positive bacteria Enterococcus faecalis and yeast Candida albicans in the concentration range of 25-50 $\mu \mathrm{g}-\mathrm{cm}$. Ade et al. (2012) synthesized Dichloro-[4-Chloro-2-(2-oxo-1, 2-dihydroindol-3-ylidene amino)-benzoic acid] (ACBAI) aquo complexes of $\mathrm{Ti}(\mathrm{IV}), \mathrm{Zr}(\mathrm{IV})$ and $\mathrm{Cd}(\mathrm{II})$ chloride and proposed uninegative tridentate nature of (ACBAI) ligand. Hakimi et al. (2011) synthesized (isatin-3thiosemicarbazone) -bis- (triphenylphosphine) copper(I) nitrate and reported monoclinic structure of it. In the study of the production of 1, 2, 4-oxadiazole [4, 5-a] indolones, Jiang et al., (2017) reported the lactam-lactim tautomerization of isatin depending on the nature of solvents.

Therefore, designing of new complexes of diamino isatin based Schiff base ligand still possess considerable research value. In the present work, we would like to synthesize 
zirconium(IV) complex of $\mathrm{N}, \mathrm{N}^{\prime}$-bis (isatin) diamine schiff base ligands, where diamines are ethane-1,2-diamine, propane-1,3-diamine and hexane-1,6-diamine. As a bioactive element zirconium complexes have clinical importance. The isotope ${ }^{89} \mathrm{Zr}$ has been applied to the tracking and quantification of molecular antibodies with positron emission tomography (PET) camera (Rij et al., 2011). Zirconium-containing compounds are used in many biomedical applications including dental implants and other restorative practices, knee and hip replacements, and middle-ear ossicular chain reconstruction (Lee et al., 2010). Although, well defined experimental study on zirconium complexes stated above, $\mathrm{N}, \mathrm{N}^{\prime}$-bis (isatin) diamine ligands with zirconium have not yet been done. In this context, the synthesis of $\mathrm{N}, \mathrm{N}^{\prime}$-bis (isatin) diamino zirconium (IV) complex $\left[\mathrm{ZrL}^{\mathrm{n}} \mathrm{Cl}_{2}\right]$ is considered as a new attempt.

\section{Materials and methods}

Some N, N'-bis (isatin) diamine type ligands were prepared by using isatin with diamines. The origin of ethane-1,2-diamine, propane-1,3-diamine and hexane-1,6-diamine used in this research were Scharlau, SPAIN; Isatin or [1H-indole-2,3-dione] from BDH, UK; Zirconyl Chloride $\left(\mathrm{ZrOCl}_{2} .8 \mathrm{H}_{2} \mathrm{O}\right)$ from E.merck, Germany. Methanol and ethanol were used as supplied from Scharlau, Spain, DMSO from India and DMF from Guangdong, China. All of the chemicals and solvents were analytical grade and were used without further purification.

\section{Preparation of $N$, $N^{\prime}$-bis (isatin) diamine ligands}

$\mathrm{N}, \mathrm{N}^{\prime}$-bis (isatin) diamine ligands were prepared through the condensation reactions of isatin and diamines as in the reported procedure (Goyat et al., 2016; Khalifa and Hassaan,1995). Isatin (2 mmol) was dissolved in $25 \mathrm{~cm}^{3}$ hot methanol with continuous stirring and allowed to cool. Then $1 \mathrm{mmol}$ diamine (ethane-1,2-diamine, propane-1,3-diamine and hexane-1,6-diamine) was introduced in the prepared methanolic solution of isatin. After that, the whole mixture was refluxed for three hours. Finally, the precipitate was obtained inside the reaction vessel. There after the precipitate was filtered off, washed with methanol and dried over silica gel in vacuum desiccators. The reaction for ligand preparation is shown in Scheme A.

Preparation of $N, N^{\prime}$-bis (isatin) diamino zirconium (IV) complex $\left[\mathrm{ZrL}^{n} \mathrm{Cl}_{2}\right]$

To prepare $\mathrm{ZrL}^{\mathrm{n}} \mathrm{Cl}_{2}(\mathrm{n}=1,2,3)$ type $\mathrm{N}, \mathrm{N}^{\prime}$-bis (isatin) diamino zirconium (IV) complex, $1 \mathrm{mmol}$ of zirconyl chloride was dissolved in the $30 \mathrm{~cm}^{3}$ ethanol. Then $1 \mathrm{mmol}$ prepared ligand was added to this solution with constant stirring. After a complete stirring for three hours a reddish precipitate came out. This precipitate was filtered off, washed with ethanol and dried under vacuum over silica gel. A few drops of $\mathrm{H}_{2} \mathrm{SO}_{4}$ was added to the mixture to pace the precipitation of $\mathrm{N}$, $\mathrm{N}^{\prime}$-bis (isatin)-1,2-diamino zirconium (IV) dichloride complex. Here, $\mathrm{ZrL}^{1} \mathrm{Cl}_{2}, \mathrm{ZrL}^{2} \mathrm{Cl}_{2}$ and $\mathrm{ZrL}^{3} \mathrm{Cl}_{2}$ denotes $\mathrm{N}$, $\mathrm{N}^{\prime}$-bis(isatin)-1,2-diaminoethane zirconium (IV) complex, $\mathrm{N}, \quad \mathrm{N}^{\prime}$-bis (isatin)-1,3-diaminopropane zirconium (IV) complex and $\mathrm{N}, \mathrm{N}^{\prime}$-bis (isatin)-1, 6-diaminohexane zirconium (IV) complex, respectively. The reaction for complex preparation is shown in Scheme B.

Analysis

Melting points, an important property of the ligands as well as of the complexes were performed by an Electro thermal Melting Point Apparatus of Stuart, model SMP 10, UK. The elemental analysis of ligands and complexes were done by CHEMMOL V1.0 analyzer and metal analysis by Shimadzu AA-7000, AAS using GFA-7000. Conductometer model HANNA (HI 2300) was used in conductivity measurements of prepared samples. N, N-dimethyl-formamide (DMF) was used as solvent for conductivity measurements. The FT-IR spectra were run on $\mathrm{KBr}$ pellet and recorded with FT-IR 8400S Shimadzu spectrophotometer in the range 4000-400 $\mathrm{cm}^{-1}$ at $2 \mathrm{~cm}^{-1}$ resolution and 30 times scanning. ${ }^{1} \mathrm{H}-\mathrm{NMR}$ spectra of samples in DMSO solvent were run using BRUKER $400 \mathrm{MHz}$ NMR spectrometer. Electronic absorption spectra were recorded on single beam Optizen UV Spectrophotometer in DMF solution using $1 \mathrm{~cm}$ cell. Table I shows the physical data of the prepared ligands and complexes.

\section{Results and discussion}

\section{Elemental analysis}

The percentage of elements of Ligands $\left(\mathrm{L}^{1}, \mathrm{~L}^{2}\right.$ and $\left.\mathrm{L}^{3}\right)$ and their corresponding $\mathrm{Zr}$ (IV) complexes are shown in Table I. The experimental results are comparable to the calculated values for the ligands $\left(\mathrm{L}^{1}, \mathrm{~L}^{2}\right.$ and $\left.\mathrm{L}^{3}\right)$ and their respective $\mathrm{Zr}$ (IV) complexes. These indicate almost similar elemental composition of synthesized ligands and complexes to the expected structure.

\section{Molar conductance}

The electrolytic nature of the complexes can be obtained from their molar conductance $(\Lambda)$ measurement. The molar conductance values of the prepared zirconium (IV) complexes of the $\mathrm{N}, \mathrm{N}^{\prime}$-bis (isatin) diamine schiff base ligands found very low which is depicted in Table I. The low molar conductivity of all complexes suggest their 
Table I. Physical data, elemental analysis and conductance data of the prepared N, N'-bis (isatin) diamine Schiff base ligands $\left(\mathrm{L}^{1}, \mathrm{~L}^{2}\right.$ and $\left.\mathrm{L}^{3}\right)$ and their zirconium complex $\left[\mathrm{ZrL}^{1} \mathrm{Cl}_{2}\right],\left[\mathrm{ZrL}^{2} \mathrm{Cl}_{2}\right]$ and $\left[\mathrm{ZrL}^{3} \mathrm{Cl}_{2}\right]$

\begin{tabular}{|c|c|c|c|c|c|c|c|}
\hline \multirow[t]{2}{*}{ Ligands } & \multicolumn{2}{|c|}{ Physical data } & \multicolumn{4}{|c|}{ Elemental analysis } & \multirow{2}{*}{$\begin{array}{c}\text { Conductivity dat } \\
\text { Molar conductance } \\
\mathrm{ohm}^{-1} \mathrm{~cm}^{2} \mathrm{~mol}^{-1} \\
\text { (Solvent: DMF) }\end{array}$} \\
\hline & Color & $\begin{array}{c}\text { Yield } \\
\%\end{array}$ & $\begin{array}{l}\text { m.p. } \\
\left({ }^{\circ} \mathrm{C}\right)\end{array}$ & $\begin{array}{l}\mathrm{C} \% \\
(\mathrm{Cal})\end{array}$ & $\begin{array}{l}\mathrm{H} \% \\
\mathrm{Cal}\end{array}$ & $\begin{array}{l}\mathrm{N} \% \\
\mathrm{Cal}\end{array}$ & \\
\hline $\mathrm{L}^{1}$ & $\begin{array}{l}\text { Deep } \\
\text { Yellow }\end{array}$ & 70 & 206 & $\begin{array}{l}63.50 \\
(67.92)\end{array}$ & $\begin{array}{l}4.03 \\
(4.40)\end{array}$ & $\begin{array}{l}14.96 \\
(17.61)\end{array}$ & -- \\
\hline $\mathrm{L}^{2}$ & Yellow & 72 & 190 & $\begin{array}{l}69.46 \\
(68.67)\end{array}$ & $\begin{array}{l}4.88 \\
(4.82)\end{array}$ & $\begin{array}{l}14.77 \\
(16.87)\end{array}$ & -- \\
\hline$L^{3}$ & Yellow & 72 & 182 & $\begin{array}{l}69.46 \\
(70.59)\end{array}$ & $\begin{array}{l}5.95 \\
(5.88)\end{array}$ & $\begin{array}{l}14.87 \\
(14.97)\end{array}$ & -- \\
\hline $\mathrm{ZrL}{ }^{1} \mathrm{Cl}_{2}$ & Red & 76 & 222 & $\begin{array}{l}31.86 \\
(44.98)\end{array}$ & $\begin{array}{l}2.48 \\
(2.92)\end{array}$ & $\begin{array}{l}8.73 \\
(11.66)\end{array}$ & 12 \\
\hline $\mathrm{ZrL}^{2} \mathrm{Cl}_{2}$ & Red & 74 & 200 & $\begin{array}{l}28.56 \\
(46.13)\end{array}$ & $\begin{array}{l}2.75 \\
(3.24)\end{array}$ & $\begin{array}{l}5.69 \\
(11.33)\end{array}$ & 10 \\
\hline $\mathrm{ZrL}^{3} \mathrm{Cl}_{2}$ & Red & 79 & 195 & $\begin{array}{l}30.07 \\
(49.23)\end{array}$ & $\begin{array}{l}3.78 \\
(4.10)\end{array}$ & $\begin{array}{l}6.27 \\
(10.44)\end{array}$ & 17 \\
\hline
\end{tabular}

Calculated values are given in the parenthesis.

non-electrolytic character (Uddin et al. 2012). This revealed that all ligands were covalently bonded with zirconium.

\section{FT-IR Spectra}

The infrared studies help to demonstrate the functional groups of the ligands and bonded in the complexes. FTIR spectra of the prepared N, N'-bis(isatin) diamine Schiff base iigands and their zirconium (IV) complexes are shown in Fig. 1 and 2, respectively. The spectra of the ligands should contain stretching bands for the azomethine group $((>\mathrm{C}=\mathrm{N}-$ group), $\mathrm{C}-\mathrm{N}$ and $\mathrm{C}=\mathrm{O}$ bonds at $1625-1582 \mathrm{~cm}^{-1}$ (Singh et al., 2012), 1020-1250 $\mathrm{cm}^{-1}$ (Uddin et al., 2012) and 1730-1750 $\mathrm{cm}^{-1}$ (Konstantinovic et al., 2015) regions, respectively. The vibrational frequency at $3150-3300 \mathrm{~cm}^{-1}$ (Ade et al., 2012) and $1460 \mathrm{~cm}^{-1}$ (Konstantinović et al., 2015) correspond stretching and bending vibration of N-H bond. The broad IR band at 3400-3500 $\mathrm{cm}^{-1}$ (Ade et al., 2012; Legzdins et al.,1989) arises due to the stretching vibration of $\mathrm{O}-\mathrm{H}$ in water molecule. In the present experiment, we observed vibrational band at $1608-1610 \mathrm{~cm}^{-1}$ for the synthesized $\mathrm{N}$,
$\mathrm{N}^{\prime}$-bis (isatin) diamine ligands, which can be assigned for the azomethine group $(>\mathrm{C}=\mathrm{N}-)$. This supports the formation of ligands through the condensation of isatin and diamine. The IR band at $1741-1751 \mathrm{~cm}^{-1}$ refered to the stretching vibration in $\mathrm{C}=\mathrm{O}$ bond of the ligands. The FT-IR band for stretching and bending vibration of $\mathrm{N}-\mathrm{H}$ bond was observed at 3234-3267 $\mathrm{cm}^{-1}$ and $1463 \mathrm{~cm}^{-1}$, respectively. The peak at $1203-1234 \mathrm{~cm}^{-1}$ indicated the presence of the C-N both in prepared ligands and complexes. The broad band observed at 3448 - $3454 \mathrm{~cm}^{-1}$ relating to $\mathrm{O}-\mathrm{H}$ stretching frequencies for moisture.

According to literature survey, $\bar{v}(\mathrm{M}-\mathrm{O})$ and $\bar{v}(\mathrm{M}-\mathrm{N})$ ( where, $\mathrm{M}$ indicates metal) generally shows FT-IR band at 580-595 $\mathrm{cm}^{-1}$ and $430-460 \mathrm{~cm}^{-1}$ (Ade et al., 2012) respectively. The obtained FT-IR band at $650-750 \mathrm{~cm}^{-1}$ and $447-472 \mathrm{~cm}^{-1}$ indicated the presence of $\mathrm{Zr}-\mathrm{O}$ and $\mathrm{Zr}-\mathrm{N}$ bonds in complexes. The decrease of the sharpness of $\bar{v} \mathrm{C}=\mathrm{O}$ band (at $1732-1737 \mathrm{~cm}^{-1}$ ) as well as the disappearance of $\bar{v} \mathrm{~N}-\mathrm{H}$ and $\delta$ $\mathrm{N}-\mathrm{H}$ bands in the FT-IR spectra of complexes as compared to free ligand indicated that, on complexation the possible 
<smiles>O=C1Nc2ccccc2C1=O</smiles>

Isatin<smiles>CC(CN)CN</smiles>

Diamine<smiles>[Y]C(C)CN=C1C(=O)Nc2ccccc21</smiles>

$\mathrm{N}, \mathrm{N}^{\prime}$-bis (isatin) diamine $\left(\mathrm{L}^{\mathrm{n}}\right)$

Where $\mathrm{x}=0,1$ and 4

Scheme A. Possible synthetic route of $\mathrm{N}, \mathrm{N}^{\prime}$-bis (isatin) diamine ligand $\left(\mathrm{L}^{\mathrm{n}} ; \mathrm{n}=1,2\right.$ and 3 )

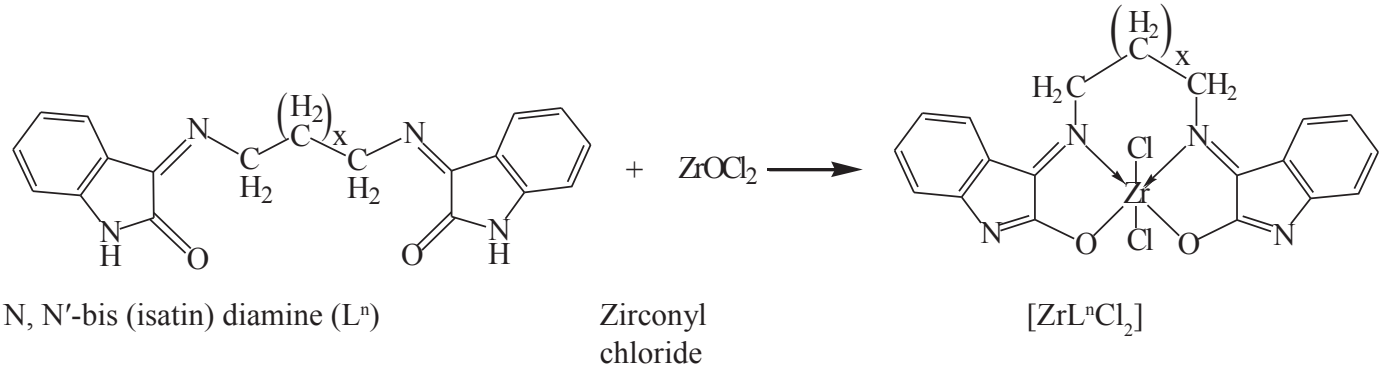

Where $\mathrm{x}=0,1$ and 4

Scheme B. Possible synthetic route of $\mathrm{N}, \mathrm{N}^{\prime}$-bis (isatin) diamino zirconium(IV) complex $\left[\mathrm{ZrL}^{\mathrm{n}} \mathrm{Cl}_{2}\right](\mathrm{n}=1,2$ and 3$)$.

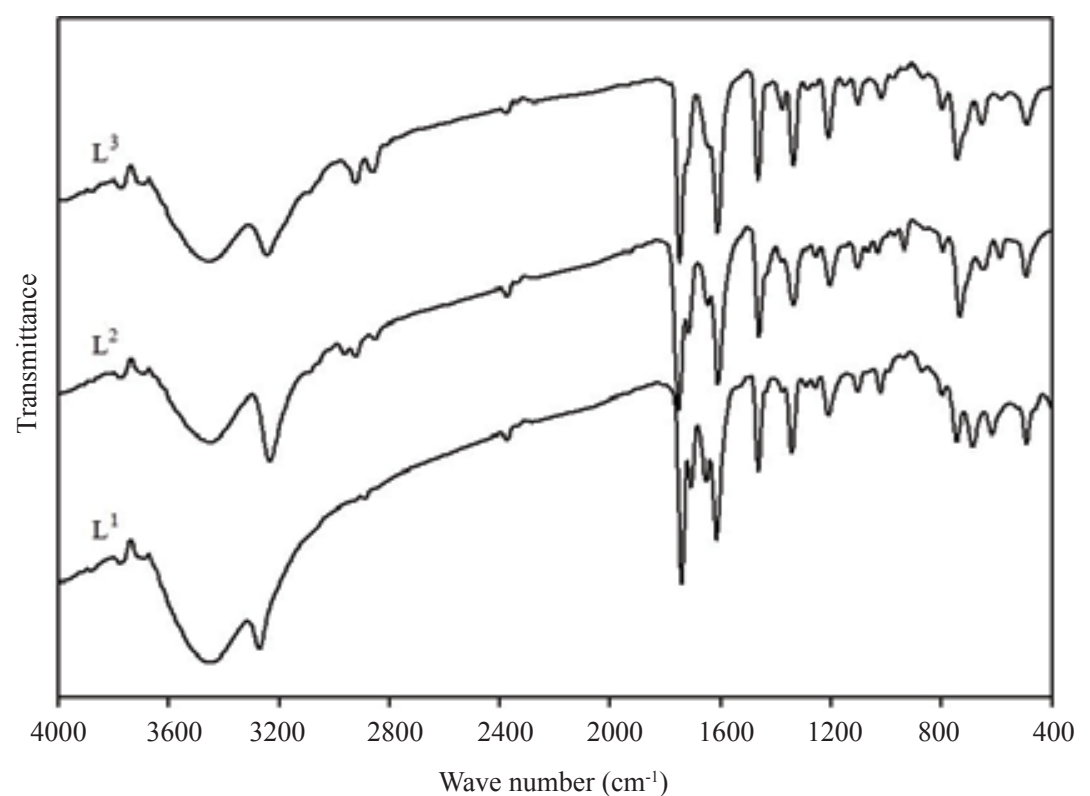

Fig. 1. FT-IR spectra of $N, N^{\prime}$-bis (isatin) diamine ligands $\left(L^{n}\right.$ where $n=1,2$ and 3$)$ 


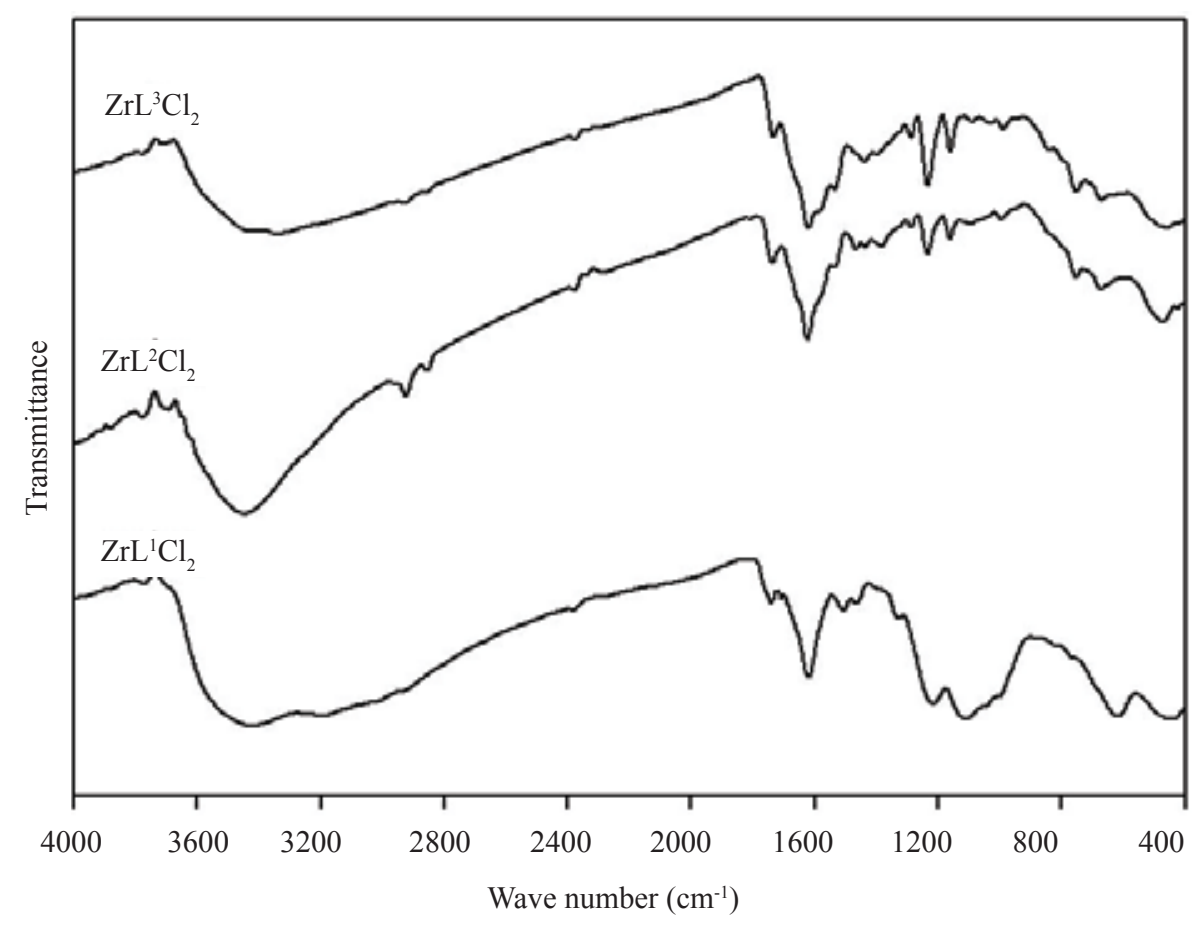

Fig. 2. FT-IR spectra of $\mathrm{N}, \mathrm{N}^{\prime}$-bis (isatin) diamino zirconium(IV) complexes $\left(\mathrm{ZrL}^{\mathrm{n}} \mathrm{Cl}_{2}\right.$ where, $\mathrm{n}=1,2$ and 3$)$

deprotonation of $\mathrm{N}-\mathrm{H}$ took place via the contiguous carbonyl oxygen in the isatin moiety through lactam-lactim tautomerism (Khalifa and Hassaan, 1995; Jiang et al., 2017). The characteristic vibrational band of azomethine group $(>\mathrm{C}=\mathrm{N}-)$ was observed at $1620-1624 \mathrm{~cm}^{-1}$ in zirconium complex which was shifted to the higher frequency compared to ligand. This shifting can be explained due the participation of azomethine nitrogen in the coordination with Ziconium in the complex. Therefore, the FT-IR spectra of complexes support the formation of $\left[\mathrm{ZrL}^{\mathrm{n}} \mathrm{Cl}_{2}\right]$ complexes through the formation of coordination bonds with $\mathrm{O}, \mathrm{N}$ donor. FT-IR spectral data for ligands and complexes are published in Table II and Table III, respectively.

\section{${ }^{1} H$ NMR Spectra}

${ }^{1} \mathrm{H}$ NMR analysis of $\mathrm{N}, \mathrm{N}^{\prime}$-bis (isatin)-1, 3-diaminopropane ligand $\left(\mathrm{L}^{2}\right)$ and $\mathrm{N}, \mathrm{N}^{\prime}$-bis (isatin)-1, 3-diaminopropane zirconium(IV) complex $\left[\mathrm{ZrL}^{2} \mathrm{Cl}_{2}\right]$ were recorded using DMSO as solvent. ${ }^{1} \mathrm{H}$ NMR of the prepared ligand and complex are shown in Fig. 3 and 4, respectively. ${ }^{1} \mathrm{H}$ NMR spectral studies of Schiff base ligand usually give signals at $\delta$ $=6.47-7.67 \mathrm{ppm}$ corresponding to aromatic protons $(\mathrm{m}, 7 \mathrm{H}$, Ar-H) and at $\delta=9.0-10 \mathrm{ppm}$ due to isatin moiety $\mathrm{NH}$ (Khalifa and Hassaan, 1995; Ade et al., 2012). According to

\section{Table II. Infrared spectral data of N, N'-bis (isatin) diamine Schiff base ligands}

\begin{tabular}{cccccc}
\hline Ligands & $\begin{array}{c}\bar{v} \mathrm{C}=\mathrm{N} \\
\mathrm{cm}^{-1}\end{array}$ & $\begin{array}{c}\bar{v} \mathrm{C}-\mathrm{N} \\
\mathrm{cm}^{-1}\end{array}$ & $\begin{array}{c}\bar{v} \mathrm{C}=\mathrm{O} \\
\mathrm{cm}^{-1}\end{array}$ & $\begin{array}{c}\delta \mathrm{N}-\mathrm{H} \\
\mathrm{cm}^{-1}\end{array}$ & $\begin{array}{c}\bar{v}-\mathrm{H} \\
\mathrm{cm}^{-1}\end{array}$ \\
\hline $\mathrm{L}^{1}$ & 1610.56 & 1203.58 & 1741.72 & 1463.97 & 3267.41 \\
$\mathrm{~L}^{2}$ & 1608.63 & 1203.58 & 1751.36 & 1462.04 & 3234.62 \\
$\mathrm{~L}^{3}$ & 1610.56 & 1209.37 & 1749.44 & 1463.97 & 3244.27 \\
\hline
\end{tabular}


Table III. Infrared spectral data of N, N'-bis (isatin) diamino $\mathrm{Zr}$ (IV) complexes

\begin{tabular}{|c|c|c|c|c|c|}
\hline Complexes & $\begin{array}{c}\bar{v} \mathrm{C}=\mathrm{N} \\
\mathrm{cm}^{-1}\end{array}$ & $\begin{array}{c}\bar{v} \mathrm{C}-\mathrm{N} \\
\mathrm{cm}^{-1}\end{array}$ & $\begin{array}{c}\bar{v} \mathrm{C}=\mathrm{O} \\
\mathrm{cm}^{-1}\end{array}$ & $\begin{array}{c}\overline{\mathrm{v}} \mathrm{Zr}-\mathrm{O} \\
\mathrm{cm}^{-1}\end{array}$ & $\begin{array}{c}\bar{v} \mathrm{Zr}-\mathrm{N} \\
\mathrm{cm}^{-1}\end{array}$ \\
\hline $\mathrm{ZrL}^{1} \mathrm{Cl}_{2}$ & 1620.21 & 1215.15 & 1735.93 & 614.34 & 447.49 \\
\hline $\mathrm{ZrL}^{2} \mathrm{Cl}_{2}$ & 1624.06 & 1234.44 & 1737.86 & 673.16 & 472.56 \\
\hline $\mathrm{ZrL}^{3} \mathrm{Cl}_{2}$ & 1620.21 & 1232.51 & 1732.06 & 671.23 & 459.06 \\
\hline
\end{tabular}

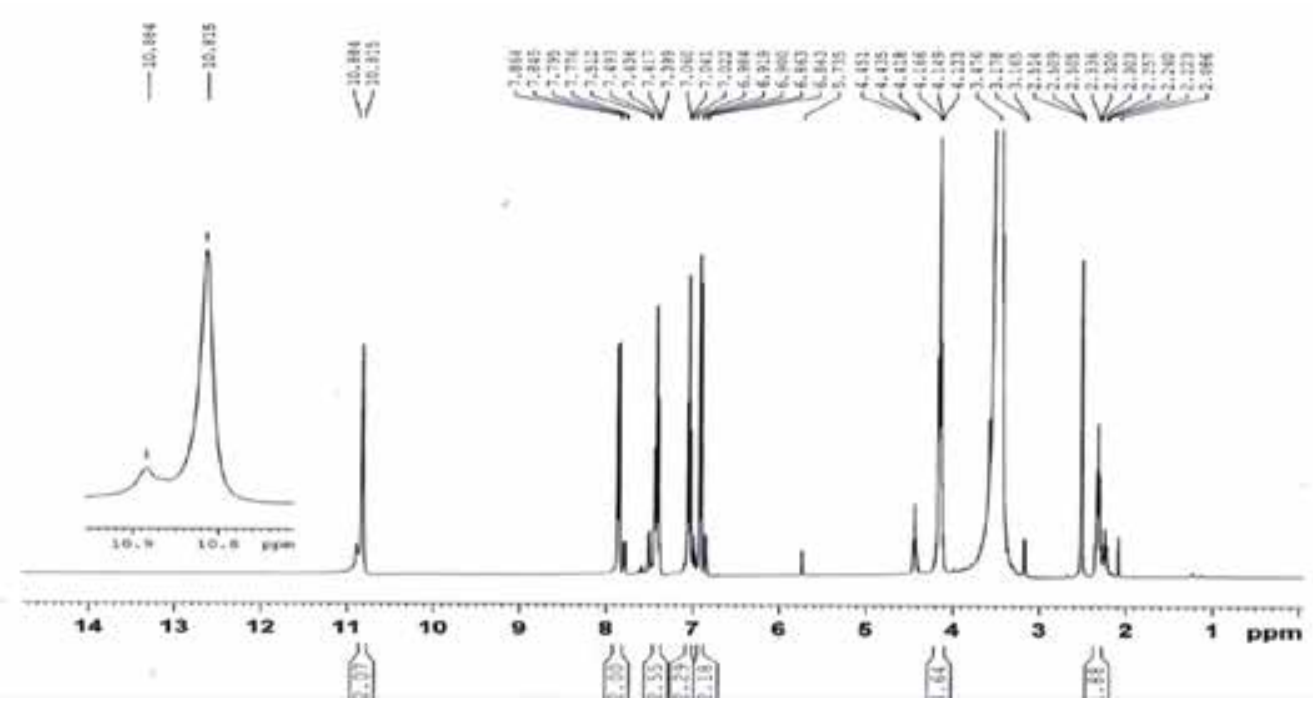

Fig. 3. ${ }^{1} \mathrm{H}$ NMR spectrum of $\mathrm{N}, \mathrm{N}^{\prime}$-bis (isatin) 1, 3-propylenediamine ligand $\left(\mathrm{L}^{2}\right)$

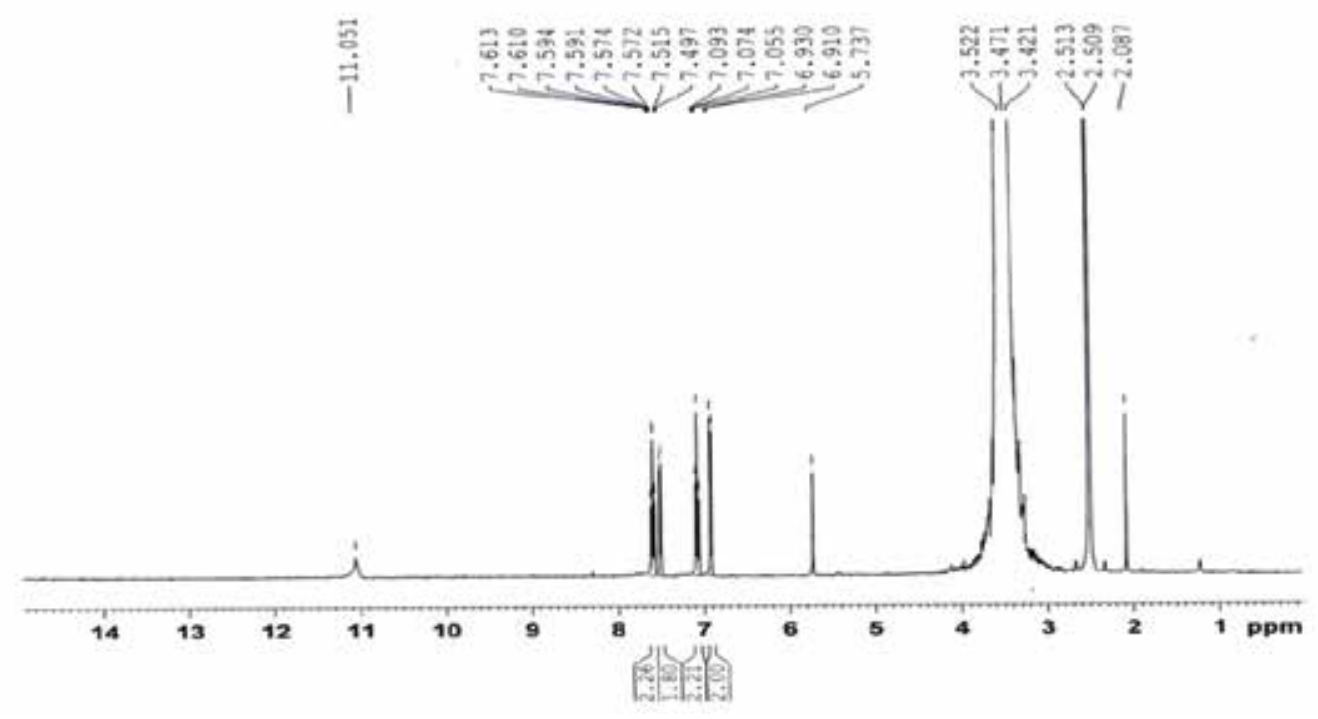

Fig. 4. ${ }^{1} \mathrm{H}$ NMR spectrum of zirconium complex of $\mathrm{N}, \mathrm{N}^{\prime}$-bis (isatin)-1, 3-diaminopropane ligand $\left[\mathrm{ZrL}^{2} \mathrm{Cl}_{2}\right]$ 
the proposed structure of selective ligand and complex, there are two types of $-\mathrm{CH}_{2}$ groups in both ligand and complex that comes from the diamine. First one is two terminal $-\mathrm{CH}_{2}$ and second one is middle $-\mathrm{CH}_{2}$ group. For middle $-\mathrm{CH}_{2}$ group multiplate was obtained at $\delta=2.240-2.336 \mathrm{ppm}$ with the integrated value 1.8 and the terminal $-\mathrm{CH}_{2}$ protons assigned from triplet at the range $\delta=4.133-4.166 \mathrm{ppm}$. There are two terminals $-\mathrm{CH}_{2}$ group in the ligand therefore, the integrated value for these protons was 4.64. The presence of these peaks proves that the aliphatic chain is present in the ligand that bridges two isatin moiety and support the formation of ligand. The phenyl protons were observed at the chemical ligand indicate the existence of ligand in the complex. The peak obtained in $\delta=10.815-10.884 \mathrm{ppm}$ for ligand was assigned for $\mathrm{NH}$ proton of isatin moiety. The N-H protonic peak in the complex gets almost disappeared through downfield shifting to $\delta=11.051 \mathrm{ppm}$ with respect to the ligand and indicated the lactam-lactim equilibrium (Khalifa and Hassaan, 1995; Jiang et al. 2017). Therefore, the ${ }^{1} \mathrm{H}$ NMR also support the FT-IR result.

\section{Electronic spectra}

The N, N'-bis (isatin) diamine ligands and their $\mathrm{Zr}$ (IV) complexes are soluble in DMSO and DMF but insoluble in

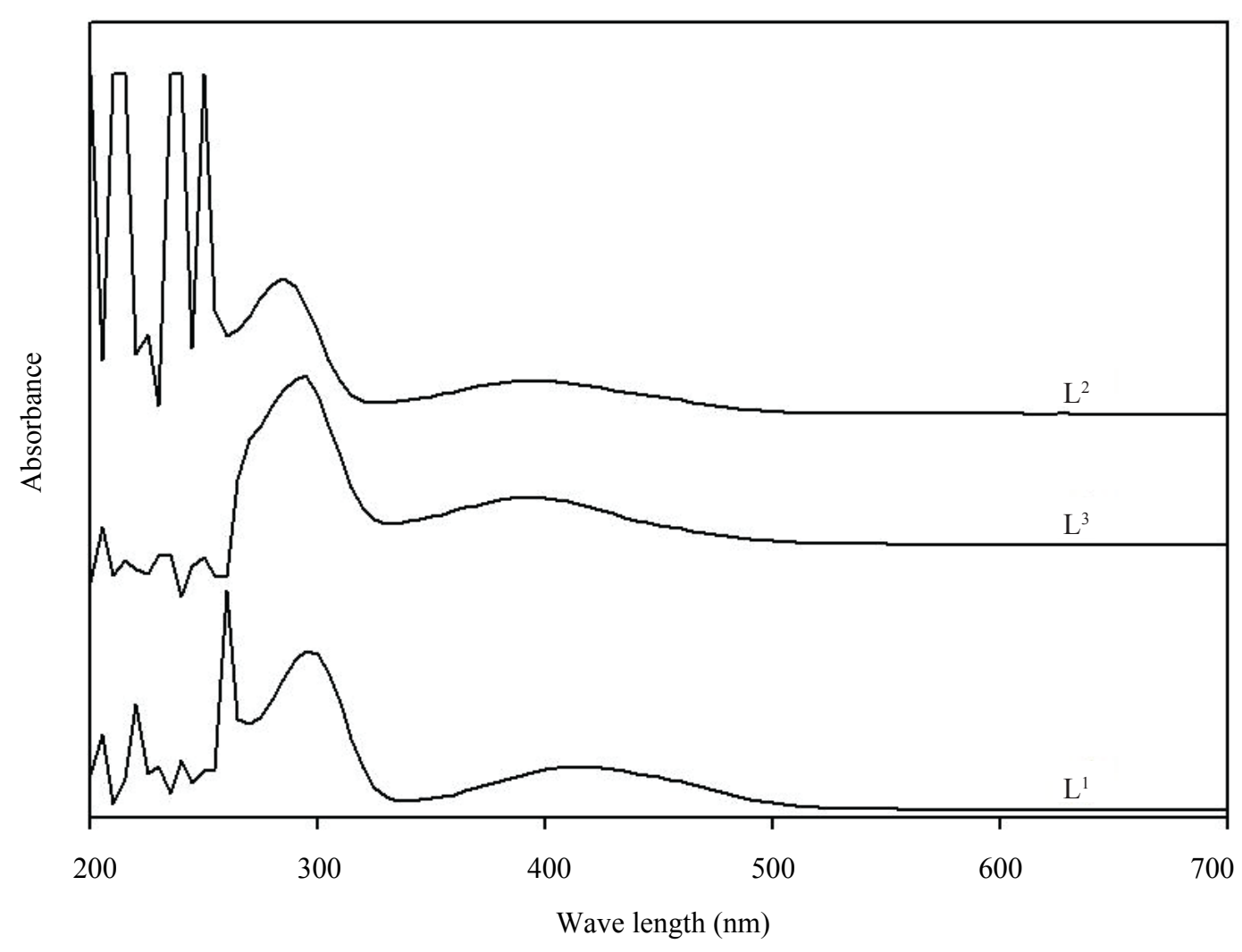

Fig. 5. UV-visible spectra of $\mathrm{N}, \mathrm{N}^{\prime}$-bis (isatin) diamine ligands

shift $\delta=6.863-7.864 \mathrm{ppm}$ for ligand and in $\delta=6.910-7.613$ for the complex. The obtained integrated values of protons on phenyl part for ligand were 2.18, 2.29, 2.55 and 2.00 and that for complex were $2.00,2.21,2.80$ and 2.26, respectively which indicate the presence of two phenyl groups in both the ligand and complex. The peaks for these two phenyl groups with eight integrated protons in the complex as like as methanol, ethanol, and $\mathrm{CCl}_{4}$. Therefore, the electronic spectra of Schiff bases and its zirconium complexes were recorded in DMF. The UV spectra of the ligands and their complexes are shown in the Fig. 5 and 6, respectively. The electronic spectra of Schiff base ligand exhibit bands at 230, 290 due to $\pi-\pi *$ transition and $380 \mathrm{~nm} \mathrm{n}-\pi^{*}$ transitions (Kriza and Parnau, 2001). In the UV spectra of ligands, bands at 240,260 and $295 \mathrm{~nm}$ can be assigned due to the $\pi-\pi^{*}$ 


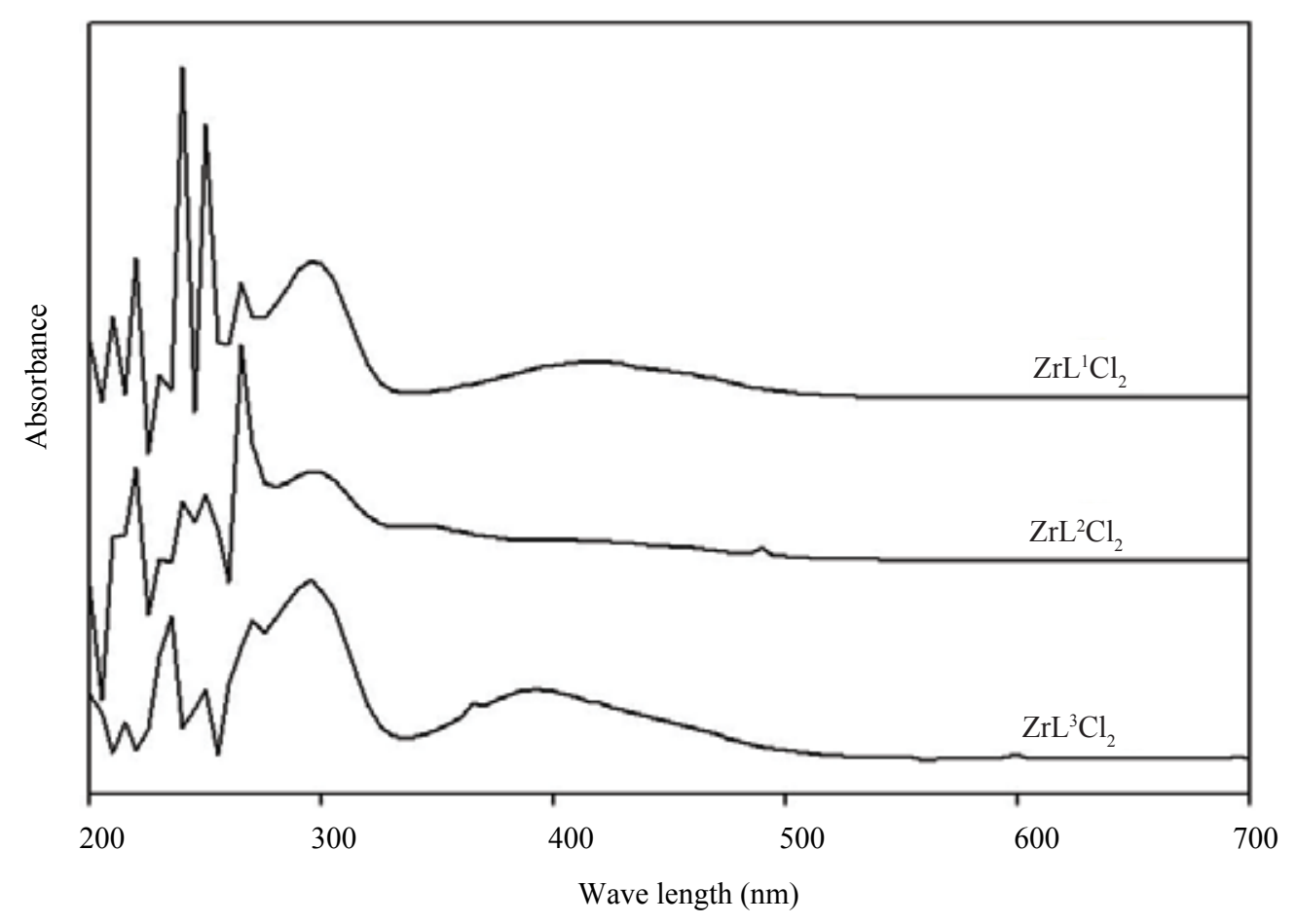

Fig. 6. UV-visible Spectra of N, N'-bis (isatin) diamino zirconium (IV) complexes

Table IV. Electronic spectral data for the N, N'-bis (isatin) diamino ligands.

\begin{tabular}{ccc}
\hline Ligands & Medium & Electronic spectral bands in (nm) \\
\hline $\mathrm{L}^{1}$ & DMF & $220,240,260,295,415$ \\
$\mathrm{~L}^{2}$ & DMF & $221,235,250,285,395$ \\
$\mathrm{~L}^{3}$ & DMF & $220,250,290,385$ \\
\hline
\end{tabular}

Table V. Electronic spectral data of $\mathbf{N}, \mathrm{N}^{\prime}$-bis (isatin) diamino zirconium (IV) complexes

\begin{tabular}{ccc}
\hline Ligands & Medium & Electronic spectral bands in (nm) \\
\hline $\mathrm{ZrL}^{1} \mathrm{Cl}_{2}$ & DMF & $240,250,265,295,395$ \\
$\mathrm{ZrL}^{2} \mathrm{Cl}_{2}$ & DMF & 270,295 \\
$\mathrm{ZrL}^{3} \mathrm{Cl}_{2}$ & DMF & $235,250,270,295,395$ \\
\hline
\end{tabular}


transitions within the aromatic ring which remain almost unchanged in the spectra of zirconium complexes. Another band at $385-415 \mathrm{~nm}$ is due to the $\mathrm{n}-\pi^{*}$ transitions within the $>\mathrm{C}=\mathrm{N}$ - group. The $\mathrm{d}-\mathrm{d}$ electronic transition generally shows band around 550nm but pure d-d origin are not expected in the zirconium (IV) complexes having $4 \mathrm{~d}^{0}$ configuration (Jafarpour et al., 2013). In the UV spectra of present complexes, there was no absorption band found beyond 500 $\mathrm{nm}$. This revealed the absence of $\mathrm{d}-\mathrm{d}$ electronic transition over the visible region. Thus the electronic spectral data clearly confirmed that the complexes are genuine zirconium (IV). The complexes are, however, colored only through their absorptions tailing in the form of ultraviolet. Electronic spectral data are shown in Table IV and $\mathrm{V}$ for the prepared complexes.

\section{Conclusion}

The N, N'-bis (isatin) diamino Schiff base ligands were prepared by the usual condensation of isatin and diamine like ethane-1, 2-diamine, propane-1,3-diamine and hexane-1,6-diamine in 1:2 molar ratio. Zirconium complexes of these prepared ligands were synthesized by the reaction of the ligands and zirconium (IV) oxychloride octahydrate $\left(\mathrm{ZrOCl}_{2} \cdot 8 \mathrm{H}_{2} \mathrm{O}\right)$. The prepared ligand and complexes were found to be of the type $\mathrm{L}^{\mathrm{n}}$ and $\mathrm{ZrL}^{\mathrm{n}} \mathrm{Cl}_{2}$ (where, $\mathrm{n}=1,2,3$ ). The analytical data indicated that the complexes have 1:1 (metal:ligand) stoichiometry. Molar conductance value indicated the non-electrolytic nature of the prepared complexes. Azomethine $\bar{v} \mathrm{C}=\mathrm{N}$ band in the FT-IR spectra indicating the successful formation of ligands. The shifting of $\bar{v} \mathrm{C}=\mathrm{N}$ band to the higher frequency in complexes indicated the influence of coordination of ligand with zirconium. The disappearance of $\bar{v} \mathrm{~N}-\mathrm{H}$ and $\delta \mathrm{N}-\mathrm{H}$ bands and de-intensification of $\bar{v} \mathrm{C}=\mathrm{O}$ indicated the lactam-lactim equilibrium. The appearance of $\overline{\mathrm{v}} \mathrm{Zr}-\mathrm{O}$ and $\overline{\mathrm{v}} \mathrm{Zr} \leftarrow \mathrm{N}$ modes indicated the formation of metal-ligand coordination compound In ${ }^{1} \mathrm{H}$ NMR spectra the peaks for eight integrated protons of two phenyl groups and protons for methylene groups of bridging diamines in both the ligands and complexes pointed out their existence. The peak for $\mathrm{NH}$ proton at $\delta=10.815-10.884 \mathrm{ppm}$ of ligand gets almost disappeared in the complex indicated deprotonation through tautomerism due to the formation of coordinate bond and support the FTIR result. In the electronic spectra we observed absorption bands in the range below $500 \mathrm{~nm}$. The absence of peak above $500 \mathrm{~nm}$ suggested that there is no electron in the $\mathrm{d}$ orbital of zirconium metal. It reveled the formation of complexes where zirconium exists in +4 oxidation state. The elemental analysis showed good agreement of experimental and theoretical percentage of $\mathrm{C}, \mathrm{H}$, and $\mathrm{N}$ in both ligands and their complexes. On the basis of overall analysis in this research, the formation of $\mathrm{N}, \mathrm{N}^{\prime}$-bis (isatin) diamino zirconium (IV) complex $\left(\mathrm{ZrL}^{\mathrm{n}} \mathrm{Cl}_{2}\right)$ with octahedral geometry could be expected. However, without crystal structure determination, it is difficult to put forward the exact geometry of $\mathrm{ZrL}^{\mathrm{n}} \mathrm{Cl}_{2}$ complexes. Therefore, further study is required to illustrate the precise structure of the prepared complexes and the mode of reaction.

\section{References}

Ade SB, Deshpande MN and Deshmukh JH (2012), Synthesis and characterization of transition metal complexes of Schiff base derived from isatin and 2-amino, 4-chloro benzoic acid, RASĀYAN J. Chem. 5(1): 10-15.

Goyat G, Malik A, Garg S and Verma KK (2016), Studies on some propylenediamine-bis (isatin) Schiff base complexes of tellurium (IV), Der Pharma Chemica 8(2):198-203.

Goyat G, Malik A, Garg S and Verma KK (2016), Studies on some tellurium(IV) complexes of $\mathrm{N}, \mathrm{N}$-Bis(indol -2-oxo-3-ylidene)-1,2-Diaminoethane, Int. J. Chem. Sci. 14(1): 387-398.

Hakimi M, Vahedi H, Rezvaninezhad M, Schuh E and Mohr F (2011), Synthesis and characterization of copper (I) complexes from triphenylphosphine and isatin Schiff bases of semi- and thiosemicarbazide, Journal of Sulfur Chemistry 32(1): 55-61. DOI: 10.1080/ 17415993.2010.544042.

Jafarpour M, Rezaeifard A, Haddad R and Gazkar S (2013), A reusable zirconium (IV) Schiff base complex catalyzes highly efficient synthesis of quinoxalines under mild conditions, Transition Met Chem 10: 31-36.

Jiang KM, Luesakul U, Zhao SY, An K, Muangsin N, Neamati N, Jin $Y$ and Lin J (2017), Tautomeric-Dependent Lactam Cycloaddition with Nitrile Oxide: Facile Synthesis of 1,2,4-Oxadiazole [4,5-a] indolone Derivatives, ACS Omega. 2: 31233134. DOI: 10.1021/acsomega.7b00490. Epub.

Khalifa MA and Hassaan AM (1995), Synthesis and characterization of dioxouranium (VI), oxovanadium (IV), thorium (IV), zinc (II), cadmium (II), mercury (II) and lead (II)complexes with propylenediamine Bis-(Isatin) schiff base, Indian Journal of Chemistry 
34A: 580-583.

Khalifa MA and Hassaan AM (1995), Synthesis and characterization of some transition metal complexes with Ethylenediamine Bis-Isatin tetradentate ligand, Bull. Che. Soc. Ethiop. 9(1): 17-22.

Konstantinovic SS, Tomić J, Savic J, Zlatkovic M, Mirkovic JJ, Dugalic GVS (2015), The synthesis and antimicrobial activity of isatin-3-(4'-hydroxy) benzoylhydrazone, Advanced technologies 4(1): 49-53. DOI: $10.5937 /$ savteh1501049K.

Kriza A and Parnau C (2001), Complex of Ti(IV) with some bidentate Schiff base derived from 1H-indole-2, 3-dione, Acta Chim Slov. 48: 445-452.

Lee DB, Roberts M, Bluchel CG and Odell RA (2010), Zirconium: Biomedical and nephrological applications, ASAIO J. 56(6):550-556. DOI: 10.1097/ MAT.0b013e3181e73f20.

Legzdins P, Phillips EC and Sánchez L (1989), New types of organometallic oxo complexes containing molybdenum and tungsten, Organometallics 8(4): 940-949. DOI: 10.1021/om00106a013.

Mathur G and Nain S (2014), Recent Advancement in Synthesis of Isatin as Anticonvulsant Agents: A Review, Medicinal Chemistry 4: 417-427. DOI:0.4172/ 2161-0444.1000173.
Rij CMV, Sharkey RM, Goldenberg DM, Frielink C, Molkenboer JDM, Franssen, GM, van Weerden WM, Oyen WJG and Boerman OC (2011), Imaging of Prostate Cancer with Immuno-PET and Immuno-SPECT Using a Radiolabeled Anti-EGP-1 Monoclonal Antibody, The Journal of Nuclear Medicine 52(10): 1601-1607. (DOI: 10.2967/ jnumed.110.086520).

Singh HL, Singh JB and Sharma KP (2012), Synthetic, structural, and antimicrobial studies of organotin(IV) complexes of semicarbazone, thiosemicarbazone derived from 4-hydroxy-3-methoxybenzaldehyde, Research on chemical intermediates 38(1): 53-65. DOI.org/10.1007/s11164-011-0325-8).

Sonawane RP and Tripathi RR (2013), The chemistry and synthesis of 1H-indole-2,3-dione (Isatin) and its derivatives, International Letters of Chemistry, Physics and Astronomy 7(1): 30-36. DOI: org/10.18052/ www.scipress.com/ILCPA.12.30.

Uddin MN, Chowdhury DA and Hossain K (2012), Titanium(IV) Complexes of Unsymmetrical Schiff Bases Derived from Ethylenediamine and o-Hydroxyaldehyde/ Ketone and Their Anti-microbial Evaluation, J. Chinese Chem. Soc. 59(12): 1520-1527. DOI.org/10.1002/jccs.201200169. 